応の場合の最適条件を明らかにした。

終わりに発表を許可された旭電化工業株式会社取締役社長東 海林武雄氏に厚く感謝の意を表する。また本研究に当たり化学 工学的検討飞つき助言して下さった東大工学部助教授浦口勇三 氏深謝する。 (昭和 37 年 11 月 13 日受理)

1) 得能, 山本, 本誌投稿中
2) 得能, 山本, 曽我, 原田, 本誌, 10，600-6 (1961)

3) Brit., 450,732 (1936); U.S., 2,102,042 (1937)

4) 重井, 化学工学, 18, 308 (1954)

5）化学工学協会編; “化工便覧”, p. 437 (1958)

6) Gilliland, Ind. Eng. Chem., 32, 1220 (1940)

7) Drickamer, Bradford, Trans. Am. Inst. Chem. Eng., 39, 319 (1943)

\title{
グリコール系可塑剤の合成とポリ酢酸ビニルへの作用効果
} 林貞 男*。沢山勇*本山卓 彦*

\section{Synthesis of Glycol Ester Plasticizers and their Effects on Polyvinyl Acetate}

Sadao Hayashi, Isamu Sawayama and Takuhiko Motoyama

\begin{abstract}
Various kinds of plasticizers such as dialkyl glycol ester were synthesized and tested as plasticizers of polyvinyl acetate films.

Among these, as a result, dimethyl, diethyl glycol sebacate and dimethyl, diethyl, dibutyl glycol adipate had better plasticity effects and lower evaporation loss than the conventional dibutyl phthalate.
\end{abstract}

\section{1 緒 言}

ポリ酢酸ビニルは多くの可塑剤と相溶性があるが,一 般に用いられているのはジブチルフタレート (DBP) の みであって，そのほかは食品用にブチルフタリルブチル グリコレート，エマルジョンの一部にトリクレジルホス フェートが用いられているにすぎない。てれはポり酢酸 ビニルの用途がポリ塩化ビニルほどのはげしい条件で使 われるととが少ないため，可塑剤としての性質があまり 検討されておらず，わずかに Hartmann ${ }^{1)}$ の種々の可塑 剂で可塑化した皮膜の $t_{g} \delta$ が調べられている程度であ る。

一方 $\mathrm{Edbrooke}^{2)}$ はポリ酢酸ビニル皮膜の 2 次転移温 度を測定し，ジメチルグリコールセバケートが大きい可 塑効果を持っていることを述べている。

著者らはジアルキルグリコール系の各種可塑剤を合成 し，ポリ酢酸ビニルの皮膜に対する効果を調べた。

\section{2 可塑剂の合成亡性質}

合成した可塑剤はつぎの 9 種である。 $\mathrm{R}^{\prime} \mathrm{OCH}_{2} \mathrm{CH}_{2} \mathrm{OOCRCOOCH} \mathrm{CH}_{2} \mathrm{OR}^{\prime}$

$$
\begin{aligned}
& \mathrm{R}=\mathrm{C}_{4} \mathrm{H}_{9}, \quad \mathrm{C}_{6} \mathrm{H}_{13}, \\
& \mathrm{R}^{\prime}=\mathrm{CH}_{3}, \mathrm{C}_{2} \mathrm{H}_{5}, \mathrm{C}_{4} \mathrm{H}_{9}
\end{aligned}
$$

これをつぎのように略記する。

$$
\text { ジメチルグリコールアジペート }
$$

DMGA

*高分子化学工業 (株) 研究所 (大阪府寝屋川市仁和寺 434)

Research Laboratory, High Polymer Chemical Industries, Ltd.

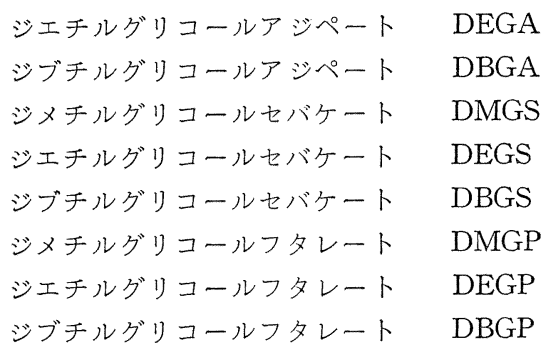

合成法は 1 価アルコール $1.1 \mathrm{~mol}$, 二塩基酸 $1 / 2 \mathrm{~mol}$, ベンゼン $1 / 2 \mathrm{~mol}$ ，濃硫酸 $0.4 \mathrm{cc}$ を留出水分分離装置 を付した三ロフラスコに入れ，コンデンサー，かきまぜ 器を付して加熱反応させる。反応温度はアルコールの種 類によって異なるが，沸点において反応させ，理論量の 水が留出したときを終点とする。反応温度 $90 \sim 150^{\circ} \mathrm{C}$

\begin{tabular}{|c|c|c|c|c|}
\hline 可塑剤 & 沸 & $\begin{array}{l}\text { 比 }{ }^{\circ} \text { 重 } \\
\left(20^{\circ} \mathrm{C}\right)\end{array}$ & $\begin{array}{l}\text { 屈折率 } \\
\left(30^{\circ} \mathrm{C}\right)\end{array}$ & 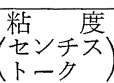 \\
\hline DMGA & $158 \sim 159^{\circ} \mathrm{C} / 2 \mathrm{mmHg}$ & 1.081 & 1.4422 & 7.84 \\
\hline DEGA & $167 \sim 169^{\circ} \mathrm{C} / 3 \mathrm{mmHg}$ & 1.042 & 1.4413 & 8.23 \\
\hline DBGA & $200 \sim 203^{\circ} \mathrm{C} / 3 \mathrm{mmHg}$ & 0.998 & 1.4432 & 10.49 \\
\hline DMGS & $202 \sim 204^{\circ} \mathrm{C} / 4.5 \mathrm{mmHg}$ & 1.027 & 1.4467 & 11.23 \\
\hline DEGS & $225 \sim 228^{\circ} \mathrm{C} / 8 \mathrm{mmHg}$ & 1.001 & 1.4453 & 12.05 \\
\hline DBGS & $238 \sim 240^{\circ} \mathrm{C} / 5 \mathrm{mmHg}$ & 0.971 & 1.4469 & 14.70 \\
\hline DMGP & $198 \sim 202^{\circ} \mathrm{C} / 6 \mathrm{mmHg}$ & 1.170 & 1.5022 & 16.15 \\
\hline DEGP & $210 \sim 213^{\circ} \mathrm{C} / 7 \mathrm{mmHg}$ & 1.121 & 1.4940 & 24.55 \\
\hline DBGP & $237 \sim 238^{\circ} \mathrm{C} / 7 \mathrm{mmHg}$ & 1.062 & 1.4862 & 25.18 \\
\hline DBP & $227 \sim 235^{\circ} \mathrm{C} / 37 \mathrm{mmHg}$ & 1.047 & 1.4296 & 14.86 \\
\hline
\end{tabular}
において $2 \mathrm{hr}$ 程度である。

表-1 合成した可塑剤の性質

反応後液を炭酸ナトリウム水溶液で洗浄，さらに水洗 
を繰り返し，水を分離したのち無水ボウ硝で乾燥し，常 圧でベンゼンを回収したのち，減圧蒸留により可塑㓮を 留出させた。

合成した可塑剤の物理的性質を DBP とともに示せば 表-1 のようである。

なおてれらの可塑剤の赤外線吸収 スペクトルを $\mathrm{DB}$ GA，DBGS，DBGP を代表して図-1 亿示す。

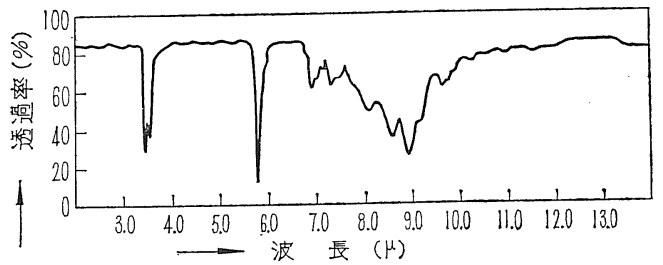

DBGA

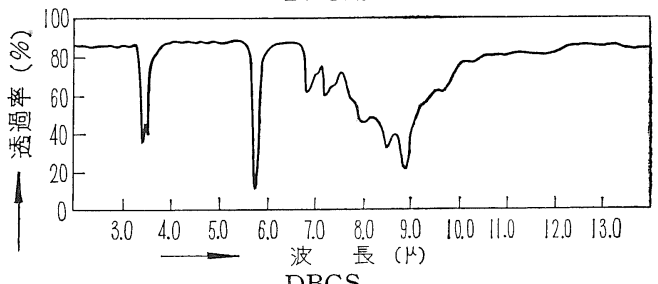

DBGS

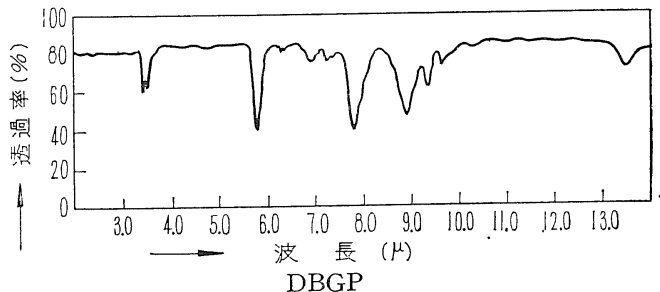

图-1 可塑凪の赤外線吸収スペクトル

\section{3 ポリ酶酸ビニルの製造}

上のように合成した可塑剤を用いつぎのような条件で ポり酢酸ビニルエマルジョンを製造した。なお比較のた めに用いた DBP は 7, 10,12.5，15\% と量を変えた が，他の可塑剤は $7 \%$ で一定とした。

表-2 エマルジョンの試験結果

\begin{tabular}{lr|c|c|c}
\hline \multicolumn{1}{c|}{ 可塑 } & 剂 & 濃度(\%) & $\mathrm{pH}$ & 凝 析 值 \\
\hline DMGA & & 33.5 & 2.8 & 0.23 \\
DEGA & & 33.5 & 2.4 & 0.41 \\
DBGA & & 32.8 & 2.4 & 0.47 \\
DMGS & & 31.3 & 2.6 & 0.23 \\
DEGS & & 33.1 & 2.6 & 0.23 \\
DBGS & & 33.2 & 2.8 & 0.16 \\
DMGP & & 32.1 & 2.6 & 0.41 \\
DEGP & & 31.7 & 2.6 & 0.16 \\
DBGP & & 32.3 & 2.6 & 0.28 \\
DBP & $(7 \%)$ & 32.6 & 2.2 & 0.33 \\
" & $(10 \%)$ & 33.0 & 2.6 & 0.16 \\
" (12.5\%) & 33.5 & 2.8 & 0.38 \\
" & $(15 \%)$ & 33.5 & 2.8 & 0.16 \\
\hline \multicolumn{2}{r|}{}
\end{tabular}

酢酸ビニルモノマー 可塑剂

非イオン界面活性剤 2.1 部 (7\% 対モ)マー)

触媒(過酸化水素系レドックス) 水を加えて全量

$\frac{\text { 適量 }}{100 \text { 部 }}$

得られたエマルジョンの試験結果は 表-2 のようであ る。

\section{4 皮膜の荷重一伸長曲線}

まずエマルジョン $6 \mathrm{cc}$ をガラス板 $(9 \times 6 \mathrm{~cm})$ 上に流 し, $30^{\circ} \mathrm{C}$ の恒温器中にて皮膜を作成した。ての皮膜を 減圧デシケータで乾燥後インストロン型引張り試験機を 用い， $20^{\circ} \mathrm{C}, 55 \%$ R.H. の恒温室内で荷重一伸長曲線を 求めた。

試料の大きさ：試長 $2.5 \mathrm{~cm}$, 幅 $0.5 \mathrm{~cm}$, 厚さ $0.04 \mathrm{~cm}$

引張り速度 : $10 \mathrm{~cm} / \mathrm{min}$ チャート速度 : $20 \mathrm{~cm} / \mathrm{min}$

(チャートのストレイン方向の $1 \mathrm{~cm}$ が伸長率 $20 \%$ に相当するので $500 \%$ 伸長が $25 \mathrm{~cm}$ 亿あたる）

測定は同一試料について 5 回行ない，最大，最小を省 略して平均をとった。図-2 亿荷重一伸長率曲線を示す。

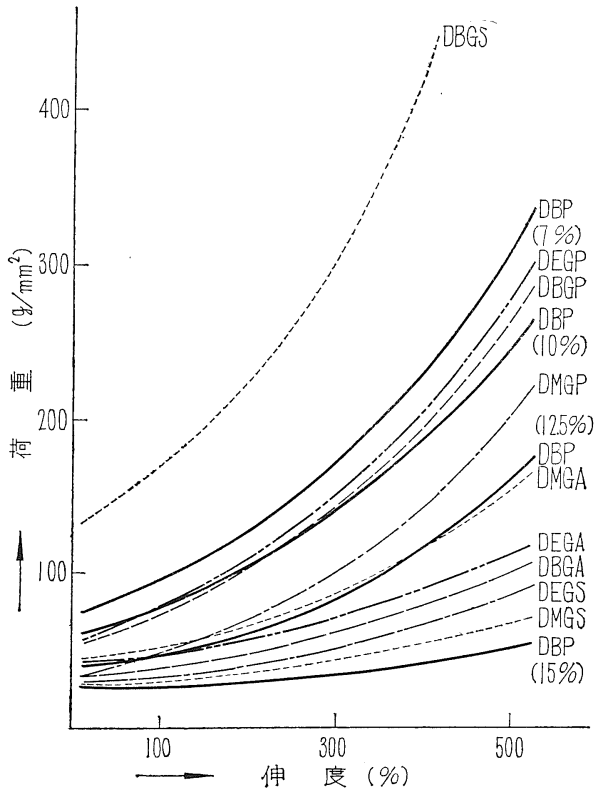

図-2 各種可塑剂によるポリ酢酸ビニル皮膜の荷重 一伸長率曲線

\section{5 加熱による可塑剂の減量}

可塑㓮 $30 \mathrm{~g}$ を径 $6 \mathrm{~cm}$ のヒョウ量ビンにとり, $110^{\circ} \mathrm{C}$, $5 \mathrm{hr}$ 加熱して蒸発減量を求めた。皮膜の加熱減量は $5 \times$ $3 \mathrm{~cm}$ の可塑剤含有皮膜を $100 \pm 2^{\circ} \mathrm{C}$ 亿 $6 \mathrm{hr} 40 \mathrm{~min}$ 加 熱したときの減量で示した。 
実験結果は 表-3 亿示すようにいずれもDBPより小 さい結果が得られた。てれは沸点が DBP よりも高いて とにもよると思われるが, 可塑剤自身の加熱減量と皮膜 からの加熱減量とが必ずしも平行していないとともあ りポリ酶酸ビニルと可塑剤との親和性も大きく影響し ていると考光られる。

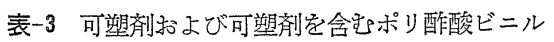
の加熱減量.

\begin{tabular}{l|c|c}
\hline 可塑 郕 & 可塑剤の加熱減量(\%) & 皮膜の加熱減量(\%) \\
\hline DMGA & 0.558 & 0.739 \\
DEGA & 0.496 & 0.803 \\
DBGA & 0.219 & 1.252 \\
DMGS & 0.104 & 0.974 \\
DEGS & 0.341 & 0.977 \\
DBGS & 0.243 & 0.932 \\
DMGP & 0.181 & 0.731 \\
DEGP & 0.407 & 0.925 \\
DBGP & 0.080 & 1.043 \\
DBP & 0.524 & 1.336 \\
\hline
\end{tabular}

\section{6 考察}

使用した可塑剤中 DBGS を除いてはいずれも DBP より柔く可塑化効果が大きい。DBGS を含むポり酶酸 ビニル皮膜は可塑剤が sweat outしているので, 混和 性が悪く可塑化効率が劣るものと思われる。図-1 の曲 線を伸長率 300，400，500\% のとてろで切り, 各可塑 剂 $7 \%$ 含有皮膜が，DBP の何 \% 含有皮膜に相当する かを調べると表-4のようになる。

つぎにてれらの効果を重量比，モル比に換算した結果 は表-5のようである。

いずれの可塑剤も DBP に比して可塑化効果が向上し
表-4 各種可塑剤と DBP との比較 (I) 各伸長率における DBP 相当量 $(\%)$

\begin{tabular}{|c|c|c|c|c|}
\hline 可塑剤 伸長率 & $\begin{array}{l}300 \% \\
\text { 伸長 }\end{array}$ & $\begin{array}{l}400 \% \\
\text { 伸長 }\end{array}$ & $\begin{array}{l}500 \% \\
\text { 伸長 }\end{array}$ & 平 均 \\
\hline DMGA & 12.9 & 12.8 & 12.8 & 12.8 \\
\hline DEGA & 13.4 & 13.7 & 13.9 & 13.7 \\
\hline DBGA & 13.9 & 14.0 & 14.1 & 14.0 \\
\hline DMGS & 14.7 & 14.7 & 14.7 & 14.7 \\
\hline DEGS & 14.5 & 14.4 & 14.4 & 144. \\
\hline DMGP & 12.3 & 12.0 & 11.4 & 11.9 \\
\hline DEGP & 8.9 & 8.9 & 9.0 & 8.5 \\
\hline DBGP & 9.6 & 9.4 & 9.5 & 9.5 \\
\hline
\end{tabular}

表一5 各種可塑冎々 DBP との比較 (II) DBP の効果を 1.00 としたときの各可塑剤の効果

\begin{tabular}{c|c|c}
\hline 可塑戍 & 重量比 & モ ル 比 \\
\hline DMGA & 1.83 & 1.72 \\
DEGA & 1.96 & 2.04 \\
DBGA & 2.00 & 2.49 \\
DMGS & 2.10 & 2.40 \\
DEGS & 2.06 & 2.57 \\
DMGP & 1.70 & 1.72 \\
DEGP & 1.27 & 1.32 \\
DBGP & 1.36 & 1.79 \\
\hline
\end{tabular}

ているが，アジペート，セバケートともに DBP の 2 㥉 くらいの効果があり, DMGS, DEGS, DBGA が最も 効果が大きいととがわかった。

（昭和 37 年 10 月 5 日受理）

$$
\text { 文 }
$$

\section{献}

1) A. Hartmann, Kolloid-Z., 153, 157 (1957)

2) P.C. Edbrooke, F.P. Gridmshaw, R.A.W. Pateman, J. Oil \& Colour Chemists' Assoc., 42, 543 (1959) 